\title{
Selection of Tolerant Lines to Salinity Derived from Durum Wheat (Triticum durum Desf.) in Vitro Culture
}

\author{
O. Ayed-Slama, S. Ayed, H. Slim-Amara \\ Department of Agronomy and Plant Biotechnology Genetic and Cereal Breeding Laboratory, Tunis, Tunisia \\ Email: olfa.slama@planet.tn, olfayed@yahoo.fr, ayedsourour@yahoo.fr, amarahajer@yahoo.fr
}

Received 10 November 2014; accepted 19 July 2015; published 22 July 2015

Copyright (C) 2015 by authors and Scientific Research Publishing Inc.

This work is licensed under the Creative Commons Attribution International License (CC BY).

http://creativecommons.org/licenses/by/4.0/

(c) (†) Open Access

\section{Abstract}

The genetic variability is considered as the major principle of plant breeding for durum wheat. This variability can be induced in vitro by selection pressure exerted by stress factors such as salinity in order to regenerate the vitro plantlets tolerant. This study aims in the first step in the regeneration of plantlets tolerant to salinity from mature embryos culture derived from two Tunisian durum wheat varieties: improved (Razzek) and landrace (Jenah Khotifa (JK)) varieties. The tolerance evaluation to salt stress was applied in vitro $\left(100 \mathrm{mmol} \cdot \mathrm{l}^{-1} \mathrm{NaCl}\right)$ and was based on various parameters. Our results showed that $\mathrm{JK}$ variety was distinguished by a stable response for all parameters tested: average weight of callus (368.1 $\mathrm{mg}$ for control and $307 \mathrm{mg}$ under salt stress), callus regenerated percentage (36.6\% for control and $35.7 \%$ under salt stress) and green shoots number/callus (17 for control and 17 under salt stress). This stability of response translates the adaptability of this variety to salinity. In order to fix regenerated JK plantlets in single generation and obtain HDs homozygous stable lines, in vitro gynogenesis technical is tested for this genotype. The Evaluation of gynogenetic capacity focused on about 1200 unfertilized ovaries of JK and was based on its ability to induction, differentiation, development of green shoots, and haploid plantlets regeneration. JK showed good tolerance to salinity and a relatively good response to gynogenesis.

\section{Keywords}

Diversity, Mature Embryos Culture, Gynogenesis, Salinity Tolerance, Triticum durum

\section{Introduction}

Cereal constitutes a strategic sector for agricultural development. Durum wheat is the most important cereal

How to cite this paper: Ayed-Slama, O., Ayed, S. and Slim-Amara, H. (2015) Selection of Tolerant Lines to Salinity Derived from Durum Wheat (Triticum durum Desf.) in Vitro Culture. Agricultural Sciences, 6, 699-706. 
crops grown in the world [1]. Wheat productivity is frequently reduced by various factors, including unfavorable growing conditions specially biotic and abiotic stresses in particular salinity [2] [3]. In Tunisia, this problem is more acute in arid and semi-arid region characterized by limited water resources, poor irrigation water quality (NaCl: 3 - $12 \mathrm{~g} / \mathrm{l}$ ) and salty soils reached 100.000 ha. This had led to serious loss of yields and productivity [4]. Currently, improvement of durum wheat varieties tolerant to salinity has been one of the main directions in breeding strategies. However, varietal selection by conventional methods is a relatively slow process (more than 10 years to create a variety). In vitro culture techniques can shorten the breeding program to create new salt tolerant genotypes and exploit all genetic variability [5]. One of the most supportive and promising breeding approaches to achieve stable salt tolerant wheat genotypes is to exploit natural diversity of the gene pool carrying desired genes for salt tolerance. In wheat species, mature and immature embryos have been used for embryogenic callus formation and plant regeneration [6]. This in vitro tissue plant method permits firstly the early selection of cereal plants tolerant to salinity through the induction of somaclonal variability using selection pressure by salt in order to induce vitrovariation and to redirect variability and to increase tolerance [4] [7].

Vitroculture allows secondly the quick release of genetic material by doubled haploid plants techniques (andogenèse, gynogenesis and intergeneric hybridization) which regenerate homozygous lines in a single generation [8]-[11].

Response of in vitro mature embryos culture of two durum wheat Tunisian genotypes to salt stress was the main objective of this study. In vitro gynogenesis technique is tested in order to fix regenerated plantlets and stabilize rapidly the traits related to salinity tolerance.

\section{Material and Methods}

\subsection{Donor Plants and Growth Conditions}

Two Tunisian durum wheat cultivars were used as donor plants in this study: Landrace variety Jenah Khotifa (JK) and improved variety Razzek. Plants were grown in the experimental fields during the normal season at the National Agronomic Institute of Tunisia; seeds were sown on the first week of November. Spikes were collected in March when microspores are at the late uninucleate or binucleate stage. Subsequently, additional tillers were collected when they reached similar morphological development stage.

\subsection{Vitro Culture of Mature Embryos}

The spikes were sterilized with Sodium hypochlorite $12 \%$ during 15 minutes followed by three washings with sterile water. Mature embryos carefully extracted were cultivated in induction medium in $10 \mathrm{~cm}$ diameter Petri dishes containing modified MS medium [12] deprived of salt at density of ten embryos per dishes (Table 1). Plates were sealed and incubated at $25^{\circ} \mathrm{C}$ with a 16 hour photoperiod at light intensity of $80-100 \mu \mathrm{E} \cdot \mathrm{m}^{-2} \cdot \mathrm{s}^{-1}$. After four weeks, embryos were transferred to different medium with gradually decreasing 2,4-D concentration as mentioned in Table 2. Salt stress $(100 \mathrm{mM})$ was applied during callus proliferation to eight weeks old calli to induce somaclonal variation. This genetic variability will permit the selection of tolerant vitroplantlets.

After one month in salt stress, some traits were noted such as callus induction percentage, average weight of callus, green shoots number and regenerated plantlets number.

\subsection{Ovary Culture and Plant Regeneration}

The tillers used for ovary culture were pretreated in cold pre-treatment $\left(14\right.$ days at $\left.4^{\circ} \mathrm{C}\right)$. After, the spikes were sterilized with $12 \%$ bleach for ten min and washed 3 times with sterilized water. The ovaries of 1 to $1.5 \mathrm{~mm}$ length were carefully extracted, and 20 ovaries were placed in $5.5 \mathrm{~cm}$ diameter Petri dishes of induction medium (Table 3). A total of 1221 unpollinated ovaries were used for this study. Cultures were sealed and kept in incubator under the dark condition [14] [15] at $27^{\circ} \mathrm{C}$ for 5 to 6 weeks. Calli obtained were transferred to a differentiation medium (Table 3) for 6 weeks at $25^{\circ} \mathrm{C}$ with a 16 hour photoperiod at light intensity of 80 - 100 $\mu \mathrm{E} \cdot \mathrm{m}^{-2} \cdot \mathrm{s}^{-1}$. The calli with emerging shoots were placed on development medium (DevM) and kept in the same conditions for regeneration. After plantlet regeneration, the cultures were transferred into jars containing $125 \mathrm{ml}$ of development medium and grown to plants.

Ind M: Induction medium;

Diff M: Differentiation medium; 
Table 1. Medium composition of [12] modified by [13].

\begin{tabular}{|c|c|c|}
\hline & Components & Concentration (mg/l) \\
\hline Macroelements & $\begin{array}{c}\mathrm{NH}_{4} \mathrm{NO}_{3} \\
\mathrm{KNO}_{3} \\
\mathrm{CaCl}_{2} \cdot 2 \mathrm{H}_{2} \mathrm{O} \\
\mathrm{MgSO}_{4} \cdot 7 \mathrm{H}_{2} \mathrm{O} \\
\mathrm{KH}_{2} \mathrm{PO}_{4}\end{array}$ & $\begin{array}{c}1650 \\
1900 \\
440 \\
370 \\
170\end{array}$ \\
\hline Microelements & $\begin{array}{c}\mathrm{H}_{3} \mathrm{BO}_{3} \\
\mathrm{KI} \\
\mathrm{Na}_{2} \mathrm{MoO}_{4} \cdot 2 \mathrm{H}_{2} \mathrm{O} \\
\mathrm{CoCL}_{2} \cdot 6 \mathrm{H}_{2} \mathrm{O} \\
\mathrm{MnSO}_{4} \cdot 7 \mathrm{H}_{2} \mathrm{O} \\
\mathrm{ZnSO}_{4} \cdot 7 \mathrm{H}_{2} \mathrm{O} \\
\mathrm{CuSO}_{4} \cdot 5 \mathrm{H}_{2} \mathrm{O} \\
\mathrm{Na}_{2} \cdot \mathrm{EDTA}^{2} \cdot 7 \mathrm{~A} \\
\mathrm{FeSO}_{4} \cdot 7 \mathrm{H}_{2} \mathrm{O}\end{array}$ & $\begin{array}{c}6.200 \\
0.828 \\
0.250 \\
0.025 \\
10.000 \\
2.000 \\
0.025 \\
37.200 \\
27.800\end{array}$ \\
\hline Vitamins & Thiamnine. HCL & 0.50 \\
\hline Aminoacids & L. Asparagine & 150 \\
\hline Growth regulators & 2,4-D & Variable \\
\hline Saccharose & & 20,000 \\
\hline Agar & & 7000 \\
\hline
\end{tabular}

Table 2. Concentration of 2,4-D in the different phases of the culture of mature embryos of durum wheat.

\begin{tabular}{ccc}
\hline Culture steps & Auxine 2,4-D (mg/l) & Number of days after culture \\
\hline Induction & 1 & 30 \\
Callus proliferation 1 & 0.75 & 60 \\
Callus proliferation 2 & 0.5 & 90 \\
Regeneration 1 & 0.25 & 120 \\
Regeneration 2 & 0 & 150 \\
\hline
\end{tabular}

Dev: Development medium.

Gynogenetic parameters used are:

$\%$ of responding ovaries: number of responding (sweeling) ovaries/ number of cultured ovaries $\times 100$.

Other parameters ( $\%$ of calli, $\%$ of green shoots, $\%$ of haploid plantlets) are based on the number of responding ovaries.

\section{Results}

\subsection{Effect of Salt on Stressed Durum Wheat Embryos}

Data in Figure 1 and Figure 2 showed that JK variety respond better than Razzek variety both for average callus weight and callus regenerated percentage as compared to the control with respectively $307 \mathrm{mg}$ weight for stressed calli and $36.6 \%$ percentage of regeneration. Razzek exhibited a decrease of embryogenesis ability with salt stress.

A difference between the control and stressed plantlets was noted (Figure 3 and Figure 4). Our results showed that in comparison with control cv Razzek regeneration of green shoots and plantlets was lower in presence of salt with respectively 9 and 28 for control and 6 and 18.88 for salt stressed.

The genotype JK showed a good ability to form green shoots and to regenerate plantlets both in the presence (17 green shoots and 7 regenerating plantlets) and absence of salt stress (same values). For the two parameters, salinity does not change results showing that stability of response for JK is evident.

The effect of salt stress induced by $100 \mathrm{mmol} / \mathrm{l}$ on calli cultures and regeneration was investigated on 2 genotypes of durum wheat. A great genetic variability observed between durum wheat calli treated with $\mathrm{NaCl}$ as 
Table 3. Composition of media for induction, differentiation and development of [16].

\begin{tabular}{|c|c|c|c|}
\hline Components & Ind $M$ & Diff M & Dev M \\
\hline \multicolumn{4}{|l|}{ Macroelements g/l } \\
\hline $\mathrm{NH}_{4} \mathrm{NO}_{3}$ & 0.160 & 0.160 & 0.160 \\
\hline $\mathrm{CaCl}_{2} \cdot 4 \mathrm{H}_{2} \mathrm{O}$ & 0.440 & 0.440 & 0.440 \\
\hline $\mathrm{MgSO}_{4} \cdot 7 \mathrm{H}_{2} \mathrm{O}$ & 0.370 & 0.370 & 0.370 \\
\hline $\mathrm{KH}_{2} \mathrm{PO}_{4}$ & 0.170 & 0.170 & 0.170 \\
\hline $\mathrm{KNO}_{3}$ & 1.900 & 1.900 & 1.900 \\
\hline FeEDTA & 0.040 & 0.040 & 0.040 \\
\hline \multicolumn{4}{|l|}{ Microelements mg/l } \\
\hline KI & 0.83 & 0.83 & 0.83 \\
\hline $\mathrm{H}_{3} \mathrm{BO}_{3}$ & 6.20 & 6.20 & 6.20 \\
\hline $\mathrm{MnSO}_{4} \cdot 2 \mathrm{H}_{2} \mathrm{O}$ & 22.30 & 22.30 & 22.30 \\
\hline $\mathrm{ZnSO}_{4} \cdot \mathbf{2} \mathrm{H}_{2} \mathrm{O}$ & 8.60 & 8.60 & 8.60 \\
\hline $\mathrm{Na}_{2} \mathrm{MO}_{4} \cdot 4 \mathrm{H}_{2} \mathrm{O}$ & 0.25 & 0.25 & 0.25 \\
\hline $\mathrm{CuSO}_{4} \cdot 5 \mathrm{H}_{2} \mathrm{O}$ & 0.025 & 0.025 & 0.025 \\
\hline $\mathrm{CoCl}_{2} \cdot 6 \mathrm{H}_{2} \mathrm{O}$ & 0.025 & 0.025 & 0.025 \\
\hline \multicolumn{4}{|l|}{ Vitamins $\mathrm{mg} / \mathrm{l}$} \\
\hline Nicotinic acid & 1 & 0.5 & 0.5 \\
\hline Pyridoxine HCL & 1 & 0.5 & 0.5 \\
\hline Thiamine HCL & 1 & 0.1 & 0.1 \\
\hline Pyruvate Na & & & 5.0 \\
\hline \multicolumn{4}{|l|}{ Aminoacids mg/l } \\
\hline Glutamine & 750 & 146 & 146 \\
\hline Glycine & - & 2.25 & 2.25 \\
\hline L-asparagine & - & - & - \\
\hline Myo-Inositol & 100 & 100 & 100 \\
\hline \multicolumn{4}{|c|}{ Growth regulators $\mathrm{mg} / \mathrm{l}$} \\
\hline 2,4-D & 2 & 1 & - \\
\hline NAA & - & 1 & - \\
\hline Kinetin & 0.5 & & - \\
\hline $2 \mathrm{iPA}$ & - & 0.1 & - \\
\hline Maltose g/l & 60 & - & - \\
\hline Saccharose g/l & - & 30 & 30 \\
\hline Purified Agar g/l & 7 & 7 & 7 \\
\hline pH & 5.8 & 5.8 & 5.8 \\
\hline
\end{tabular}

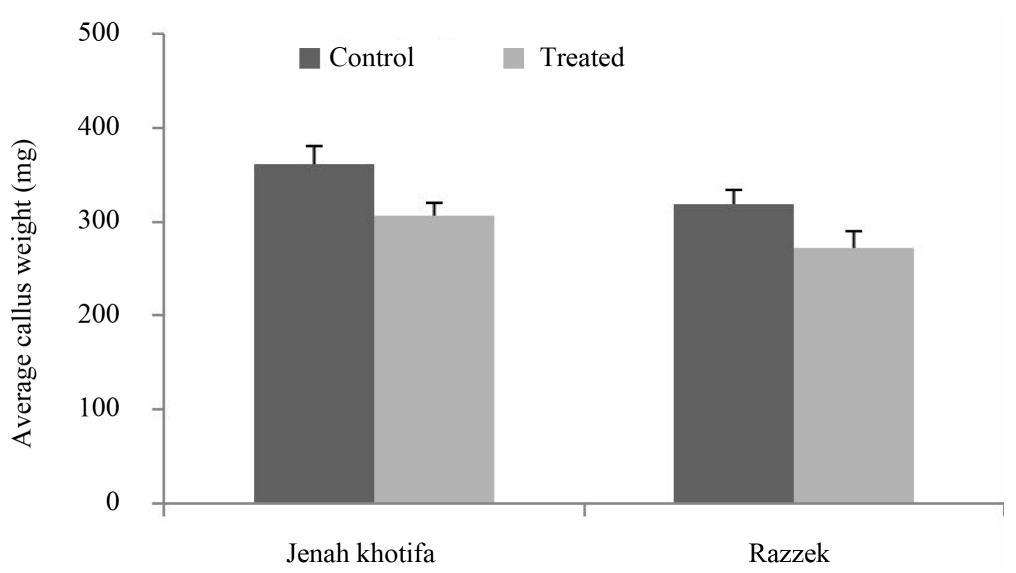

Figure 1. Variation in the average callus weight depending on genotypes tested in absence and presence of salt stress.

shown in Figure 5 and Figure 6. The number of shoots per callus is a widely used criterion to evaluate the adaptability and tolerance of genotypes deal with all types of stress including salinity. 


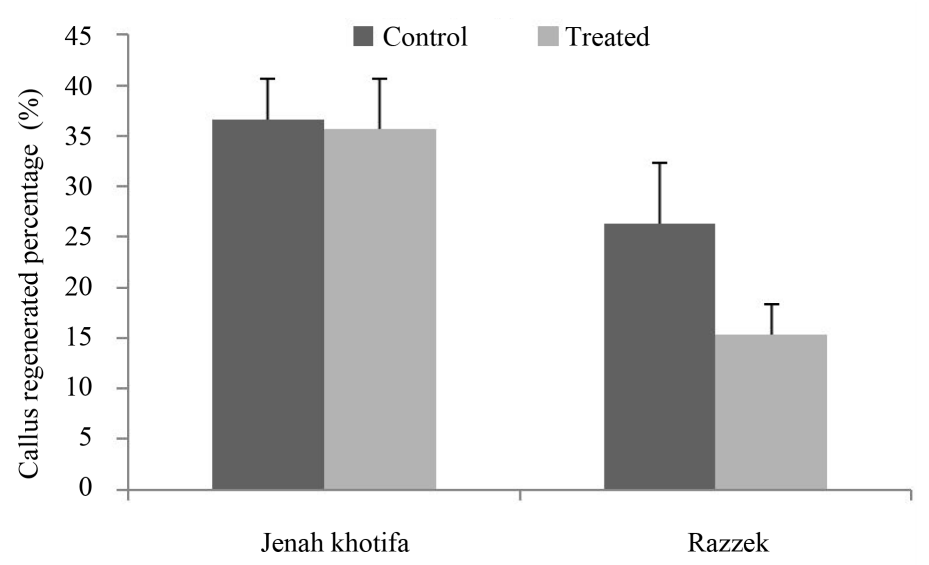

Figure 2. Variation in the average callus weight depending on genotypes tested in absence and presence of salt stress.

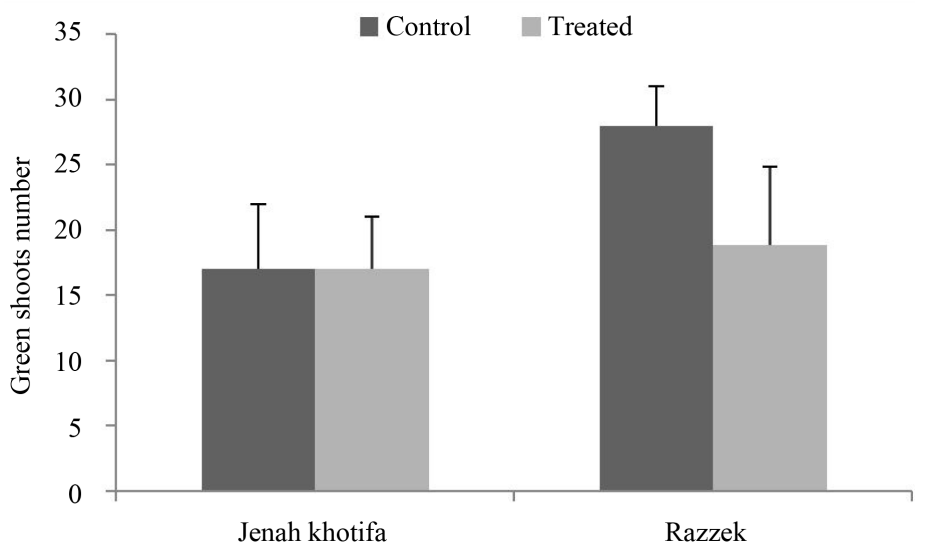

Figure 3. Variation in the average callus weight depending on genotypes tested in absence and presence of salt stress.

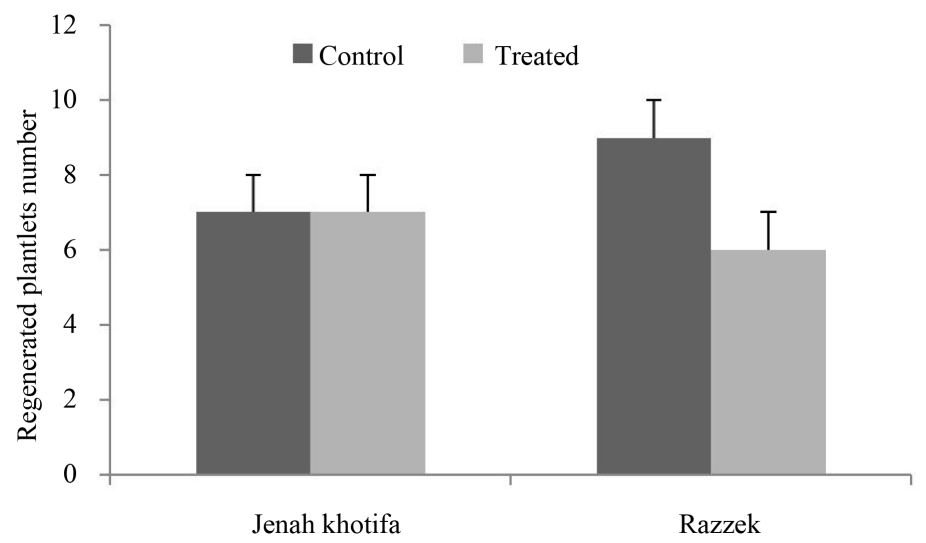

Figure 4. Variation in the average callus weight depending on genotypes tested in absence and presence of salt stress.

\subsection{Ovary Culture and Plant Regeneration}

In order to fix JK regenerated vitroplants in single generation and obtain homozygous haploid plantlets, in vitro gynogenesis technical is tested for this genotype. In this experiment we observed that $49 \%$ of ovaries cultivated 


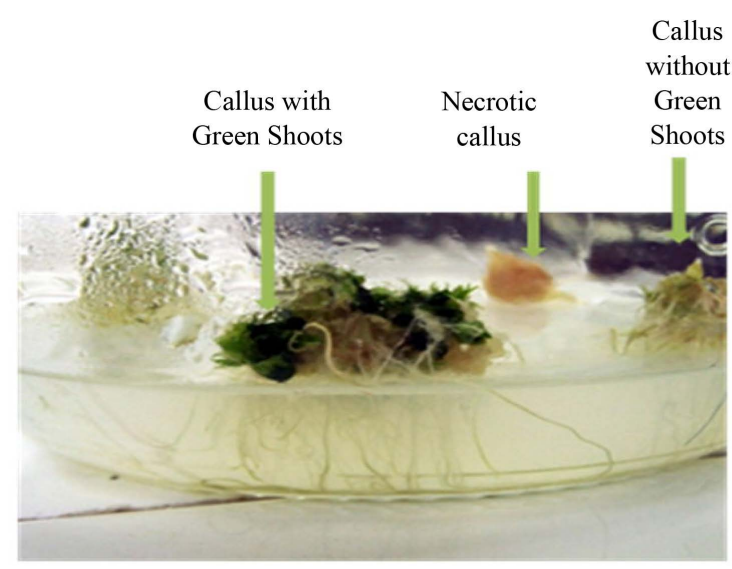

Figure 5. Different aspects of durum wheat calli after 8 weeks of culture in Ms medium with salt $(100 \mathrm{mmol} / \mathrm{l})$.

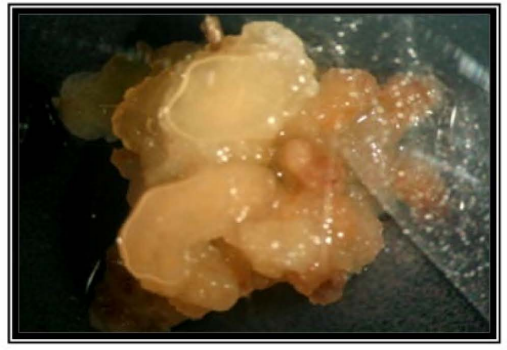

(a)

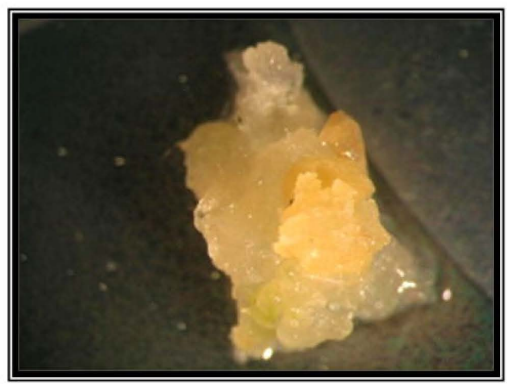

(c)

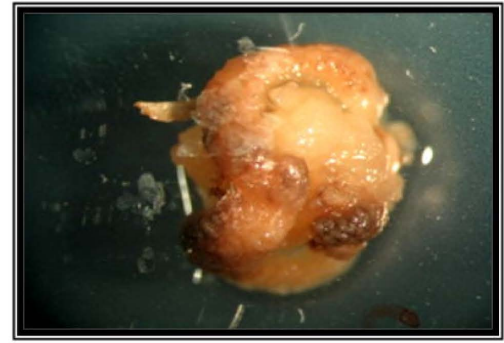

(b)

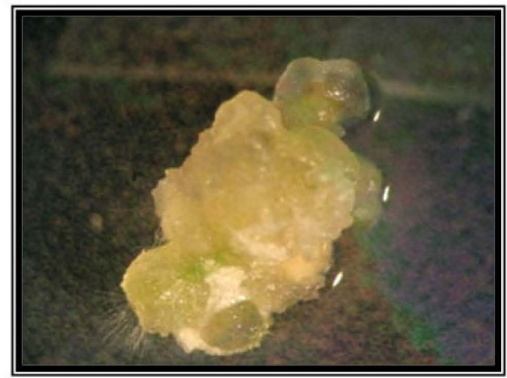

(d)

Figure 6. Aspect of calli formed in presence ((a) and (b)) and in absence of salt ((c) and (d)) (a) Calus soft brown; (b) Necrotic callus; (c) Compact callus (d) Callus with green shoot.

responded to gynogenesis, callus was induced at $3.4 \%, 5$ haploid plantlets were regenerated were obtained. JK was relatively responsive to gynogenesis and responded relatively regularly. All regenerated plants were green.

\section{Discussion}

Percentage of regenerable callus from Razzek variety, compared to JK, decreased in presence of salt in the medium. In salt stress conditions, there is a reduction in somatic embryogenesis and regeneration capacities. These competence depend on both genotype and $\mathrm{NaCl}$ concentration in the culture medium [17]. Results obtained by [18] indicated that the relative growth rate of callus decreased as the concentration of $\mathrm{NaCl}$ increased in callus. The selected callus line gave a higher growth weight in the presence of $\mathrm{NaCl}$ in the medium and was highly significant as compared with unselected callus line across medium protocols in all wheat cultivars. According to study of [6], tissue culture responses using callus induction and regeneration capacity of wheat are influenced principally by the genotypes. Indeed, a great genetic variability observed between durum calli treated with $\mathrm{NaCl}$ 
explained by the somaclonal variation. Same finding were obtained by [19] on eight durum wheat cultivars on immature embryo culture, callus production and in vitro under salt stress.

The stability of response of the Jenah Khotifa variety observed in absence and presence of salt stress translates the adaptability of this genotype to salinity. These results confirm those of [20] who noted that Jenah khotifa not showed a significant decrease in callus growth during the application of salt stress compared to control. [7] noted that cultured cell lines in vitro appear to be more sensitive than the treated material in situ. This approach can be used as an early test for the identification of new sources of salinity tolerance. Zair et al. (2003) also concluded that plant regeneration from callus initiated on high $\mathrm{NaCl}$ levels may be a valid method of selection for salt tolerance on wheat. These observations need to be confirmed in vitro and in situ culture [21].

Gynogenesis was tested for durum wheat genotype Jenah Khotifa (JK) and was responsive and produced calli, regenerated plantlets, green haploid plant. Rates of haploid plant regenerated were acceptable comparatively to previous studies with durum wheat ([10] [15] [16]). This tehnique offers great potential and has the advantage that all the haploid plants obtained are green. In fact, androgenesis has been long used to develop doubled haploid plants in cereals ([9] [22] [23]). But, in most cases, the high rate of albino plants is considered as a major limitation of this technique. This study reports an efficient protocol for developing green plants using gynogenesis of some genotypes of durum wheat. Gynogenesis is the method of choice to avoid the albino problem associated to androgenesis in durum wheat.

We will continue the doubled haploid production system in order to stabilise the apparent tolerance to salinity genotypes trying improving the rate of doubled haploid green plants obtained by amending the culture conditions and choosing a good responding cultivars. Nevertheless, the current technology itself may be widely applicable to durum wheat breeding.

\section{Conclusion}

Our results showed that JK variety was distinguished by a stable in vitro response to salt stress and it was relatively responsive to gynogenesis. This genotype could be integrated in breeding program. HDs homozygous lines obtained by gynogenesis technical for this genotype should be tested in pot and field.

\section{References}

[1] Ahmadizadeh, M., Valizadeh, M., Shahbazi, H., Zaefizadeh, M. and Habibpor, M. (2011) Morphological Diversity and Interrelationships Traits in Durum Wheat Landraces under Normal Irrigation and Drought Stress Conditions. Advances in Environmental Biology, 5, 1934-1940.

[2] Khayatnezhad, M., Zaeifizadeh, M., Gholamin, R. and Jamaati-e-somarin, Sh. (2010) Study of Genetic Diversity and Path Analysis for Yield in Durum Wheat Genotypes under Water and Dry Conditions. World Applied Sciences Journal, 9, 655-665.

[3] Kiliç, H. and Yagbasanlar, T. (2010) The Effect of Drought Stress on Grain Yield, Yield Components and Some Quality Traits of Durum Wheat (Triticum turgidum ssp. durum) Cultivars. Notulae Botanicae Horti Agrobotanici Cluj-Napoca, 38, 164-170.

[4] Zaman, B., Niazi, B.H., Athar, M. and Ahmad, M. (2005) Response of Wheat Plants to Sodium and Calcium Ion Interaction under Saline Environment. International Journal of Environmental Science and Technology, 2, 7-12.

[5] Mansouri, S., Kobaissi, A., Nziengui, H., Fakiri, M., Shakafandeh, A. and Sibi, M. (2005) Gynogenèse in vitro chez quelques variétés de blé dur du Maghreb et du Moyen Orient (Triticum durum L.) pour l'obtention de régénérants chlorophylliens, en condition de stress salins. Géo. Eco. Trop., 29, 77-88.

[6] Soliman, H.I.A. and Hendawy, M.H. (2013) Selection for Drought Tolerance Genotypes in Durum Wheat (Triticum durum Desf.) under in Vitro Conditions. Middle-East Journal of Scientific Research, 14, 69-78.

[7] Sibi, M. and Fakiri, M. (2000) Androgenèse et gynogenèse sources de vitrovariation et de tolerance à la salinité chez l'orge Hordeum vulgare. Sécheresse, 11,125-132.

[8] Picard, E., Crambes, E. and Mihamou-Ziyyat, A. (1994) L'haplodiploÏdisation: Un outil multi-usage pour la génétique et l'amélioration des céréales. Quel avenir pour l'amélioration des plantes? Ed: AUPELF-UREF. John Libbey Eurotext, Paris, 355-369.

[9] Cistué, L., Soriano, M., Castillo, A.M., Vallés, M.P., Sanz, J.M. and Echàvarri, B. (2005) Production of Doubled Haploids in Durum Wheat (Triticum turgidum L.) through Isolated Microspore Culture. Plant Cell Reports, 25, 257-264. http://dx.doi.org/10.1007/s00299-005-0047-8 
[10] Slama-Ayed, O. and Slim-Amara, H. (2007) Production of Doubled Haploids in Durum Wheat (Triticum durum Desf.) through Culture of Unpollinated Ovaries. Plant Cell Tissue and Organ Culture, 91, 125-133. http://dx.doi.org/10.1007/s11240-007-9281-9

[11] Ayed, S., Slama-Ayed, O. and Slim-Amara, H. (2011) Effect of 2,4-Dichlorophenoxyacetic Acid and Nitrate Silver on the Efficiency of Haploid Production in Durum Wheat X Maize Crosses. International Journal of Plant Breeding, $\mathbf{5}$, 101-105.

[12] Murashige, T. and Skoog, F. (1962) A Revised Medium for Rapid Growth and Bioassays with Tobacco Tissue Cultures. Physiologia Plantarum, 15, 473-497. http://dx.doi.org/10.1111/j.1399-3054.1962.tb08052.x

[13] Sears, R. and Deckard, G. (1982) Tissue Culture Variability in Wheat: CALLUS Induction and Plant Regeneration from Triticale Embryos. Corp Science, 22, 546-550. http://dx.doi.org/10.2135/cropsci1982.0011183X002200030027x

[14] Sibi, M. and Fakiri, M. (1994) Gynogenèse chez des génotypes marocains d'orge (Hordeum vulgare). In: AUPELFUREF, Ed., Quel avenir pour l'amélioration des plantes? John Libbey Eurotext, Paris, 337-344.

[15] Mdarhri-Alaoui, M., Saidi, N., Chlayah, A. and Chlayah, H. (1998) Obtention par gynogenèse in vitro de plantes haploïdes chlorophyliennes chez le blé dur. Comptes Rendus de l'Académie des Sciences-Series III-Sciences de la Vie, 321, 25-30. http://dx.doi.org/10.1016/s0764-4469(97)89622-9

[16] Sibi, M., Kobaissi, A. and Shakafandeh, A. (2001) Green Haploid Plants from Unpollinated Ovary Culture in Tetraploid Wheat (Triticum durum Desf.). Euphytica, 122, 351-359. http://dx.doi.org/10.1023/A:1012991325228

[17] Oudija, F., Ismaili, M. and Amsa, M. (2002) Effet de la concentration en $\mathrm{NaCl}$ sur l'embryogenèse somatique et sur les capacités de régénération chez le blé. African Crop Science Journal, 10, 211-219.

[18] Barakat, M.N. and Abdel-Latif, T.H. (1996) In Vitro Selection of Wheat Callus Tolerant to High Levels of Salt and Plant Regeneration. Euphytica, 91, 127-140.

[19] Arzani, A. and Mirodjagh, S.S. (1999) Response of Durum Wheat Cultivars to Immature Embryo Culture, Callus Induction and in Vitro Salt Stress. Plant Cell, Tissue and Organ Culture, 58, 67-72. http://dx.doi.org/10.1023/A:1006309718575

[20] Karmous, C. (2001) Etude de quelques critères physiologiques et biochimiques de sélection pour la tolérance à la salinité chez le blé dur: Approche intégrative. Master Dissertation, National Agronomical Institute of Tunisia.

[21] Zair, I., Chlyah, A., Sabounji, K., Tittahsen, M. and Chlyah, H. (2003) Salt Tolerance Improvement in Some Wheat Cultivars after Application of in Vitro Selection Pressure. Plant Cell Tissue and Organ Culture, 73, 237-244. http://dx.doi.org/10.1023/A:1023014328638

[22] Dogramaci-Altunetpe, M., Peterson, T.S. and Jauhar, P.P. (2001) Anther Culture Derived Regenerants of Durum Wheat and Their Cytological Characterization. The Journal of Heredity, 92, 56-64. http://dx.doi.org/10.1093/jhered/92.1.56

[23] De Buyser, J., Touraine, P., Jaiti, F. and Picard, E. (2002) Haplodiploïdisation par culture de microspores isolées de blé in vitro. Biotechnologies végétales: Techniques de laboratoire. Livre Robert Haicour, Tec et Doc Montréal, AUF, 257273. 